\title{
FUNGSI \& MAKNA BANTEN PRAYASCITA DI KOTA DENPASAR
}

\author{
Ni Ketut Sukiani \\ Universitas Warmadewa \\ ketutsukiani@gmail.com
}

\begin{abstract}
ABSTRAK
Masyarakat Hindu di Bali sangat mengenal banten dengan berbagai variasi yang ditemukan dalam pelaksanaan yadnya yang disesuaikan dengan tingkatan yadnya. Namun sayangnya belum banyak masyarakat yang memahami tentang fungsi dan makna banten khususnya banten yang sering digunakan seperti Banten Prayascita. Penelitian ini bertujuan untuk memperdalam pemahaman tentang fungsi dan makna Banten Prayascita dalam pelaksanaan yadnya. Sumber data dalam penelitian ini dengan cara melakukan tinjauan pustaka dan wawancara kepada narasumber yang berkecimpung dalam pembuatan banten. Metode penelitian menggunakan pendekatan kualitatif yang menekankan pada keutuhan sebuah fenomena budaya. Banten Prayascita merupakan seperangkat banten yang memiliki fungsi inti banten penyucian dan setiap komponen yang ada memiliki makna tersendiri yang membentuk satu kesatuan untuk memohon penyucian kepada Ida Sang Hyang Widhi Wasa. Banten Prayascita memiliki peranan istimewa dan hampir selalu digunakan dalam pelaksanaan yadnya.
\end{abstract}

Kata Kunci : Banten Prayascita, Ida Sang Hyang Widhi Wasa, yadnya

\begin{abstract}
[Title : The Function and Purpose of Banten Prayascita at Denpasar] The Hindu people in Bali is well acquainted with variations found in yadnya which adapted to its degree. But unfortunately not many people who understand about the function and meaning of banten, especially the Banten Prayascita. This aim of this study is to increase the understanding of the function and the meaning of Banten Prayascita in Yadnya. The data in this study were obtained from literature review and interviews from the banten professionals. The research method using a qualitative approach that emphasizes the integrity of a cultural phenomenon. Banten Prayascita is a set of banten that has the core function of sanctification and each component of the banten has its own meaning that form a unity to invoke the purification to Ida Sang Hyang Widhi Wasa. Banten Prayascita has a special role and is very often used in the implementation of yadnya.
\end{abstract}

Keywords: Banten Prayascita, Ida Sang Hyang Widhi Wasa, yadnya

\section{PENDAHULUAN}

Perkembangan ilmu dan teknologi memberikan kemudahan bagi masyarakat dalam mengakses informasi sehingga bisa mempengaruhi pola kehidupan dalam masyarakat. Fenomena yang muncul dalam masyarakat menjadi semakin kritis menyikapi setiap kejadian tidak terjebak dengan jawaban mule ketotermasuk kehidupan dalam pelaksanaan ajaran agama. Falsafah ajaran Agama Hindu yang menjadi dasar dalam pelaksanaan yadnya terdiri dari Tatwa, 
Susila dan Upakara yang berjalan sinergi, tidak dapat dipisahkan sebagai satu kesatuan untuk mencapai kesempurnaan. Persepsi yang berbeda muncul akibat adanya perbedaan pengalaman dan pengetahuan tentang ajaran agama sehingga ada sikap fanatik, pengeluaran tidak terarah dan kecenderungan boros. Kehidupan yadnya di masyarakat semakin dinamis, keinginan masyarakat untuk beryadnya semakin besar sehingga muncul dorongan yang kuatuntuk lebih mendalami ajaran agama, seperti memahami fungsi dan makna banten.

Banten sejatinya telah diperkenalkan semenjak masuknya Agama Hindu ke Bali dan telah menjadi bagian budaya dalam kehidupan masyarakat. Banten diduga berasal dari India masuk melalui pulau Jawa pada masa kerajaan. Selanjutnya mengalami alkulturasi dan diyakini ada beberapa banten merupakan ciptaan hasil kreasi masyarakat Bali sesuai Desa Kala Patra. Pada masa Raja Pujungan di Bali banten dikenal dengan istilah aci berdasarkan pawisik yang didapat raja bersama pendeta untuk mengatasi malapetaka, bencana yang dialami rakyatnya (Rana, 1972). Keyakinan Umat Hindu di Bali berdasarkan kepercayaan yang diwariskan leluhur bahwa banten lahir dari penyikapan pengalaman bathin yang mendalam melalui laku tapa, brata, yoga dan semadhi. Perjalanan tentang banten terus berkembang dinamis sehingga keingin tahuan masyarakat semakin besar tentang fungsi dan makna banten yang didasarkan pada sastra dan kitab kitab suci yang memuat tentang banten.

Dalam setiap pelaksanaan Panca Yadnya baik pada tingkatan nista, madya maupun utamaselalu menggunakan sarana banten sebagai simbol yang berkedudukan khas, melambangkan sifat Tuhan sebagai wujud bakti dan pelepasan ikatan yang dituangkan dalam kreatifitas manusia dalam perjalanan hidup mencari hakikat kebenaran. Banten Prayascita memiliki posisi sangat penting dan selalu digunakan dalam pelaksanaan yadnya. Fungsinya sebagai penyucian baik melengkapi Banten Biyakala, banten pemujaan, menyucikan bangunan serta penyucian atas kekeruhan pikiran dan perasaan (Mas, 2000). Dalam pelaksanaan yadnya seperti Manusa Y adnya Banten Prayascita digunakan dalam upacara ngotonin anak yang belum tanggal giginya dan jika suda tanggal giginya diganti dengan Banten Byakala (Arwati, 1993). Prayascita menurut istilah Agama Hindu berasal dari kata tebasan yang artinya sama dengan tebus atau beli sehingga tebasan berarti sarana banten untuk menebus dosa seseorang atau upacara penyucian. Banten Prayascita termasuk banten yang memiliki mutu kedewataan (Daiwi Sampad) yang berfungsi sebagai pembersihan dan mengandung nilai religius sebagai kekuatan siwa guru.

Beberapa tahun terakhir, mulai muncul polemik tentang banten di kalangan masyarakat. Keterbatasan waktu untuk menyiapkan banten bagi masyarakat yang menghabiskan waktunya lebih banyak untuk tuntutan bekerja, memilih untuk membeli banten. Fenomena menariknya ada kecendrungan meningkatnya keinginan masyarakat untuk membeli banten. Masyarakat yang sibuk bekerja, membeli banten adalah satu cara untuk tetap melaksanakan kewajiban dan keyakinan agama (Rianingsih Putu, 2004). Kondisi ini menjadi peluang ekonomi bagi masyarakat yang memiliki pengetahuan tentang banten untuk menyediakan banten. Dampaknya masyarakat hanya mengenal nama banten saja tetapi belum tentu memahami komponen yang ada beserta fungsi dan makna banten tersebut. Hal ini akan dapat menyebabkan memudarnya nilai seni dan budaya dalam kehidupan beryadnya.

Teori Fungsional Struktural merupakan teori yang menekankan pada 
keteraturan dan mengabaikan konflik, perubahan - perubahan dalam masyarakat yang digunakan dalam penelitian ini. Konsep utamanya menekankan pada fungsi, disfungsi, fungsi laten, fungsi manifest dan keseimbangan. Teori Simbol untuk menggambarkan sesuatu khususnya sesuatu immaterial, abstrak, ide, kualitas suatu objek, proses dan lainnya (Coulson dalam Titib I Made, 2003).

Penelitian yang berkaitan dengan bebantenan jumlahnya masih terbatas, diantaranya (Rasni, 1983) berjudul "Fungsi Upacara Sesayut Prayascita Gumi dalam Upacara Butha Yadnya di Kabupaten Badung", (Mas, 2000) berjudul “ Upacara Dewa Yadnya", (Suika I Wayan, 1981) berjudul "Arti dan Fungsi Lis dalam Upacara Piodalan di Pura Jagadnatha".

Berdasarkan uraian di atas nampak masyarakat belum sepenuhnya memahami fungsi dan makna Banten Prayascita dalam pelaksanaan upacara yadnya, pemahaman hanya sebatas sebagai saranan untuk penyucian sedangkan masih banyak fungsi dan makna dari setiap komponen dalam Banten Prayascita.

\section{METODE}

Lokasi penelitian ini dilaksanakan di kota Denpasar. Pendekatan kualitatif yang lebih menekankan pada keutuhan (entity) sebuah fenomena budaya bukan memandang secara sebagian (parsial). Dalam penelitian ini peneliti berusaha menggambarkan fenomena sosial secara holistik tanpa melakukan perlakuan manipulasi. Data yang diperlukan berupa data kualitatif bersumber dari teks dan konteksnya dengan sumber data berupa sumber data dokumenter dan sumber data lapangan. Pengumpulan data dilakukan melalui tinjauan pustaka, observasi terlibat dan wawancara mendalam dengan narasumber yang berkecimpung dalam pembuatan banten.

\section{PEMBAHASAN}

Dalam proses pembuatan Banten Prayascita diperlukan bahan - bahan yang akan dibentuk sebagai komponen yang memiliki bentuk dan makna masing - masing. Komponen - komponen yang disusun sebagian merupakan simbol perwujudan Ida Sang Hyang Widi Wasa. Dengan menonjolkan nilai seni mulai dari membuat, mengatur dan menyusun sehingga diperlukan ketrampilan dan kesabaran. Selanjutnya dari bentuk dan makna yang tersirat akan memberikan fungsi sebagai penyucian. Dalam pelaksanaan yadnya fungsi banten pada dasarnya sebagai sewaka atau service yaitu pelayanan yang diwujudkan dalam bentuk hasil kerja untuk dipersembahkan kepada Ida Sang Hyang Widi Wasa.

Banten Prayascita salah satu banten yang mendapatkan tempat yang sangat istimewa dalam pelaksanaan upakara, hal ini dapat dilihat karena banten ini hampir selalu dipergunakan pada setiap pelaksanaan upacara. Banten yang sarat dengan simbol, memiliki fungsi khusus sebagai penyucian agar dapat memancarkan sinar suci, sinar kebijaksanaan yang berguna bagi orang bersangkutan serta kehidupannya di dunia dapat diterima oleh Ida Sang Hyang Widi Wasa (Mas, 2000: 66). Disamping fungsi khusus Banten Prayascita memiliki enam fungsi lainnya (Arwati, 1993), sebagai berikut:

1. Alat Konsentrasi

Keterbatasan kemampuan manusia dalam mendekatkan hubungan dengan Ida Sang Hyang Widi Wasa maka banten yang sarat simbol sebagai sarana untuk membantu seseorang memusatkan pikiran dan perasaan dalam pelaksanaan yadnya sebagai wujud syukur. Dalam ajaran Catur Marga fungsi 
banten sebagai alat konsentrasi tampak pada Bhakti Marga dan Karma Marga.

Bhakti Marga untuk mencapai kebahagian tertinggi mengutamakan penyerahan diri dan pencurahan rasa diwujudkan kerinduan bertemu secara lahir dan batin yang didasari cinta kasih kepada yang dipuja beserta manifestasinya. Secara lahir wujudnya adalah persembahan banten dan secara batin melalui sembahyang, berdoa dengan memusatkan pikiran memantapkan rasa baktinya sehingga banten dibuat seni, berwarna - warni serta beraneka ragam baik bentuk maupun penataannya. Sedangkan bagi Karma Marga menekankan dengan kerja tanpa pamrih (tulus ikhlas). Kerja sebagai simbol hidup, hidup untuk beryadnya karena melalui yadnyalah semua yang hidup di dunia ini diciptakan sesuai yang ditulis dalam Bhagawadgita (III,9).

2. Persembahan atau Korban Suci

Sebagai pernyataan dari perwujudan rasa syukur manusia kepada Ida Sang Hyang Widi Wasa beserta manifestasi-NYA atas segala karunia yang dilimpahkan dan diterima sehingga dapat melaksanakan tugas dalam menjalani kehidupan di dunia. Persembahan ditujukan kehadapan yang lebih tinggi tingkatannya seperti kepada para leluhur, Dewa - Dewi, Ida Sang Hyang Widi Wasa sedangkan korban suci ditujukan kepada yang lebih rendah seperti dalam pelaksanaan upacara Butha Yadnya contohnya banten caru.

Dalam konteks ini banten juga dikenal dengan wali yang mempunyai beberapa pengertian, antara lain :

a. Wali berarti wakil

Banten merupakan wakil manusia untuk berhubungan dengan Ida Sang Hyang Widi Wasa sebagai wujud rasa syukur secara lahir dan batin. Secara lahir diwujudkan dalam bentuk banten dan secara batin dengan sembahyang dan berdoa saat upacara berlangsung.

b. Wali berarti kembali

Semua sarana upacara yang dipersembahkan itu berasal dan dibuat dari hasil ciptaan-NYA, setelah dipilih, dibuat dan diatur dengan bentuk yang indah dipersembahkan. Tujuannya untuk menciptakan keharmonisan, keselarasan dan keseimbangan. Pelaksanaan ini merupakan inti yadnya 'ikhlas berkorban " mengandung makna yang dalam, yaitu :

- Melatih diri untuk menjadi pelaksanaan upacara atau Sang Yajamana yang baik

- Selalu ikhlas dan rela dalam beryadnya

- Membina sifat tidak kikir, pemarah dan sombong

- Belajar mengurangi rasa ego dari keterikatan benda - benda duniawi

c. Wali berarti Bali

- Mendidik untuk hidup selalu bersyukur

Agama hindu merupakan jiwanya seni dan budaya yang berkembang di Bali sehingga pelaksanaan upacara dengan persembahan banten dibuat sangat indah dan beraneka ragam yang membuat Bali terkenal dengan keindahan budayanya.

3. Sarana Pendidikan Memuja Ida Sang Hyang Widi Wasa

Fungsi ini dapat dilihat sejak awal banten dibuat, bentuknya sangat unik dan rumit memerlukan pikiran yang terarah didasari penerapan dari Tri Kaya 
Parisudha. Manfaat yang dapat diambil dari fungsi sebagai saranan pendidikan adalah :

a. Melatih dan mendorong untuk selalu berusaha belajar melalui bekerja agar mampu mewujudkan upakara yang akan dipersembahkan, yadnya sebagai salah satu cara yang diyakini dapat mengurangi dosa

b. Meningkatkan kesibukan khusunya kaum wanita sehingga tidak ada waktu untuk memikirkan sesuatu yang tidak bermanfaat

c. Menjalin kerjasama dan keakraban dalam proses belajar mewujudkan upakara

d. Meningkatkan dan mengembangkan seni budaya dalam pembuatan upakara, karena upakara penuh dengan nilai simbolis dan filosofi

e. Mendekatkan pengertian, pemahaman dan penghayatan terhadap makna simbolis dan filosofis dalam upakara tersebut

\section{Sarana Penyucian}

Bila telah dapat mengwujudkan upakara maka telah mampu melepasakan atau mengendalikan diri terhadap keterikatan akan benda - benda duniawi, mampu mengwujudkan yadnya berati telah berhasil menyucikan pikiran dari rasa ego. Kemampuan dalam mengamalkan rasa yang penuh kerelaan dan keikhlasan sebagai satu cara penyucian diri secara lahiriah dan batiniah. Upakara penuh dengan makna simbolis dan filosofis dengan bahan yang dipergunakan seperti air, api, bunga, daun, buah dan sebagainya memiliki makna yang mendalam. Penggunaan air secara lahiriah sebagai sarana pembersihan sedangkan setelah menjadi tirta sebagai sarana penyucian.

Dalam banten Prayascita komponen seperti lis, peras, pebersihan, pengresikan dan lainnya sebagai sarana penyucian yang dimohonkan kepada Ida Sang Hyang Widi Wasa dan manifestasi-NYA saat diupacarakan.

5. Perwujudan Ida Sang Hyang Widi Wasa dan Manifestasi-NYA

Semua sarana yang dipakai dalam pembuatan banten memiliki arti secara simbolis, dalam bentuk sederhana dan kecil yaitu canang genten menggambarkan sebagai Tri Murti. Mengenai simbol perwujudanIda Sang Hyang Widi Wasa dijelaskan sebagai berikut :

a. Daun sirih dalam porosan sebagai simbol Dewa Wisnu

b. Pinang dalam porosan sebagai simbol Dewa Brahma

c. Kapur dalam porosan sebagai simbol Dewa Siwa

Dalam lontar Kesuma Dewa disebutkan beberapa banten memiliki simbolis seperti :

a. Banten dalam sanggar tawang sebagai simbol hulu Ida Sang Hyang Widi Wasa

b. Banten dalam sanggar tutuan sebagai simbol dari bahu dan tangan Ida Sang Hyang Widi Wasa sedangkan banten dalam asagan sebagai simbol badan-NYA

c. Banten caru sebagai simbol perut-NYA

d. Banten dalam panggungan sebagai kaki-NYA

e. Banten dalam pesalang sebagai tempat-NYA berpijak saat memberikan anugerah pada kita

f. Semua jejahitan sebagai simbol kulit-NYA

6. Sarana Peningkatan Estetika

Banten selalu dipersembahkan dalam bentuk yang indah dan menarik, menonjolkan nilai seni sebagai wujud cita, rasa dan karsa dari manusia 
Vol. 3, No. 1, Januari 2019, 89

Available Online at https://ejournal.warmadewa.ac.id/index.php/kulturistik DOI: dx.doi.org/10.22225/kulturistik.3.1.953

sehingga selalu melekat dalam kehidupan. Nilai estetika akan terlihat bagaimana menyusun mulai dari alas banten berupa jejahitan, jajan, buahbuahan, nasi, lauk pauk atau rerasmen, hiasan serta cara pengaturan sehingga tampak indah. Pada saat dipersembahkan akan diiringi dengan seni tabuh, tarian dan nyanyian suci sebagai ungkapan rasa bakti umat sehingga upakara berlangsung semarak dan meriah. Beberapa keuntungan akan dapat diperoleh dalam pelaksanaan upakara, diantaranya :

a. Dapat membuka lapangan kerja sehingga akan dapat menampung tenaga kerja

b. Meningkatkan perkembangan perekonomian sehingga meningkatkan kemakmuran

c. Meningkatkan gizi keluarga karena bahan upakara dibuat dari 4 sehat yang dapat dinikmati sebagai anugrah Ida Sang Hyang Widi Wasa

d. Suasana desa tempat upacara akan menjadi semarak, meriah, berkesan dan menarik

e. Menciptakan rasa gembira bagi pelaksana upakara yang tampak jelas pada saat melakukan persembahyangan

Fungsi banten dapat diuraikan menjadi 5 fungsi (Sudarsana I B Putu, 2002), sebagai berikut :

1. Upakara sebagai Korban Suci

Terkait dengan si pelaksana upakara (Sang Yajamana) yang secara pribadi memiliki tanggung jawab dan kewajiban spritual baik terhadap Ida Sang Hyang Widi Wasa maupun alam lingkungannya sehingga pelaksanaan upakara disertai dengan ketulusan hati

2. Upakara sebagai Sarana Pengampunan

Terkait dengan kesalahan atau dosa pribadi yang dilakukan secara sadar atau tidak sadar. Disamping itu secara spritual memiliki makna psikologi agar selalu meningkatkan diri dalam kehidupan spritual, terhindar dari perbuatan tecela dalam berkarma. Dapat juga menghidarkan diri dari tekanan jiwa sebagai contoh dalam upakara penebusan, upakara pawetonan, guru piduka, pembayaran sesangi dan lain sebagainya

3. Upakara sebagai Sarana Penyupatan (Pengruwat)

Menetralisir atau menormalkan kembali ketidak seimbangan manusia denganIda Sang Hyang Widi Wasa, lingkungan serta antar manusia, sebagai contoh upakara pemerasan anak, upakara caru, yadnya sesa, upakara mepepade (upakara bagi hewan sebelum disembelih), upakara tumpek wariga, upakara tumpek uye dan lain sebagainya

4. Upakara sebagai Pengobatan

Upakara dapat memberikan nilai mukjizat dalam hal proses mempercepat penyembuhan dari suatu penyakit, sebagai contohnya upakara pengadeg semaya, upakara pelelabanan, upakara melukat dan lain sebagainya

5. Upakara sebagai Sarana Penyucian

Sebagai sarana penyucian terhadap buana agung maupun buana alit, memiliki fungsi dan tujuan menjaga keseimbangan sesuai ajaran Tri Hita Karana, contohnya upakara Sugian Bali, upakara Sugian Jawa, upakara Tawur Kesanga, upakara Melasti dan lain sebagainya.

Dalam setiap banten termasuk Banten Prayascita selalu mengandung sarana 
yang berwujud benda / material dan sarana yang tidak berwujud benda/ non material (Wiana, 2000). Bahan yang menjadi komponen penyusun dalam banten memiliki makna berdasarkan sarana upakara dan makna berdasarkan bentuk jejahitan.

Pembahasan makna banten berdasarkan sarana upakara disesuaikan dengan wujud material dalam banten, sebagai berikut :

1. Bunga, Daun dan Buah

\section{a. Bunga}

Dalam ajaran Agama Hindu bunga memiliki makna yang sangat penting sebagai simbol Siwa dan sebagai sarana persembahyangan. Sebagai simbol Ida Sang Hyang Widi Wasa digunakan saat melakukan persembahyangan, diletakkan diantara cakupan telapak tangan dan selanjutnya diletakkan disalah satu sela daun telinga. Sebagai simbol sarana upakara digunakan untuk sesajen yang akan dipersembahkan kepada leluhur dan Ida Sang Hyang Widi Wasa. Dalam lontar Yajna Prakerti seperti dikutip Wiana, 2000 sebagai berikut sekare pinake ketulusan pikayunan suci yang artinya bahwa bunga adalah lambang ketulusan ihklasan pikiran yang suci. Dalam sastra agama (Bhagawadgita Bab IX Sloka 26) disebutkan unsurunsur pokok yang digunakan sebagai sarana persembahyangan kehadapan Ida Sang Hyang Widi Wasa, bunyi sloka tersebut :

Patram puspam phalam toyam, Yo me bhaktya prayacchati, Rad aham bhakty-upahrtam, Asnami prayatatmanah

artinya :

Siapapun dengan sujud bhakti kepadaKu mempersembahkan sehelai daun, sekuntum bunga, Sebiji buah-buahan, seteguk air, Aku terima sebagai bakti persembahan dari orang yang berhati suci.

Bunga sering dimaknai sebagai lambang sifat kasih dan sayang dari Tuhan, bahkan sering juga dilambangkan sebagai restu Tuhan. Hal ini dapat ditemukan dalam cerita- cerita Arjuna Wiwaha restu Tuhan digambarkan dengan taburan bunga. Bunga dilukiskan seperti jiwa dan alam pikiran, jiwa atau Sang Hyang Atman yang merupakan sumber hidup atau roh. Ungkapan pikiran juga dapat dilukiskan dengan bunga misalnya dalam upacara kematian. Adanya bunga, beras kuning dan uang kepeng yang dikenal dengan sekar ura ditaburkan di setiap pertigaan atau perempatan dalam perjalanan jenasah dari rumah duka ke kuburan. Simbolis bunga dalam hal ini dimaknai ketulusikhlasan untuk melepaskan orang yang telah meninggal dengan harapan mendapatkan tempat yang layak. Dalam pelaksanaan upakara secara umum semua bunga boleh digunakan kecuali beberapa bunga yang tidak boleh digunakan (Sudarsana I B Putu dkk., n.d.), diantaranya : Bunga Mitir Bangkai, Bunga Sedap Malam, Bunga Nusa Indah, Bunga Tulud Nyuh, Bunga Srikonta, Bunga Jenis Bakung.

b. Kewangen

Kewangen memiliki arti keharuman yang mengandung makna untuk 
mengharumkan nama Tuhan. Berdasarkan bentuk dan unsur-unsur yang membentuk kewangen melambangkan "Ongkara". Kewangen dibuat dari daun pisang berbentuk kojong, delengkapi dengan daunan plawa dan hiasan puncaknya dibuatkan reringgitan dari janur berbentuk "cili" disetai dengan bunga. Dua uang kepeng dimasukkan dalam kojong dan jika digunakan sebagai sarana persembahyangan diisi "porosan silih asih" yang terdiri dari dua potong daun sirih diisi pinang, kapur sirih, sedemikian rupa digulung akan tampak satu lembar daun sirih bagian perutnya, satu lembar lagi bagian punggungnya. Dalam persembahyangan kewangen dipakai memuja Ida Sang Hyang Widhi Wasa dalam wujudnya Purusa Pradana (Ardhanaraswari). Istilah silih asih berarti lambang umat dalam bakti dan asih. Bila dilihat dari unsur-unsur yang membentuk kewangen maka memiliki arti dan makna simbolisnya sebagai sarana persembahyangan untuk menghubungkan diri dengan Ida Sang Hyang Widhi Wasa, Dewa-Dewi dan para leluhur. Selain sebagai sarana pokok dalam persembahyangan kewangen juga digunakan dalam berbagai upacara Panca Yadnya. Dalam upacara Pitra Yadnya kewangen bermakna sebagai pengurip-urip, pada saat pemandian jenasah kewangen diletakkan disetiap persendian yang jumlahnya hampir 22 buah. Pada saat upacara nasarin rumah kewangen bermakna sebagai pancadatu (lambang unsur-unsur alam), menjadi unsur penting dalam melengkapi banten pedagingan.

c. Canang

Merupakan sarana upakara terpenting dipergunakan sebagai sarana persembahan kepada Ida Sang Hyang Widhi Wasa atau Betara-Betari (Pemerintah Daerah Propinsi Bali, 2000). Canang atau dikenal dengan sirih adalah unsur yang sangat berperan sejak jaman dahulu, yang dipersembahkan kepada tamu yang dihormati sehingga sampai sekarang banyak digemari oleh orang tua. Sirih menjadi unsur inti dalam membuat canang dan betapun indahnya bentuk canang bila belum berisi sirih yang merupakan bahan dasar porosan belumlah canang tersebut bernilai keagamaan (Wiana, 2000).

Perlengkapan canang sebagai alas adalah ceper atau daun pisang berbentuk segi empat, di atasnya disusun berturut-turut perlengkapan lainnya : porosan, urasaris, bunga, pandan harum dan wangi-wangian. Makna dari masing-masing unsur dalam canang dapat diuraikan sebagai berikut :

1) Porosan

Porosan terdiri dari kapur sirih, pinang dan dibungkus dengan daun sirih. Dalam lontar Yadnya Prakerti disebutkan pinang, kapur dan sirih adalah lambang pemujaan terhadap kekuatan Tri Murti. Pinang lambang pemujaan Dewa Brahma, Sirih lambang pemujaan Dewa Wisnu dan Kapur lambang pemujaan Dewa Siwa. Tri Murti merupakan tiga perwujudan manifestasi Ida Sang Hyang Widhi Wasa yang mempunyai kekuatan menciptakan, memelihara dan melebur semua yang ada dalam kehidupan. Manusia dalam kehidupan sehari-hari memerlukan ketiga unsur tersebut dalam rangka 
menuju peningkatan hidup yang layak dan semakin baik.

2) Plawa

Plawa daun-daunan merupakan simbol pikiran hening dan suci. Keberadaan plawa dalam banten akan mampu menuntun manusia menuju keheningan dan kesucian pikiran sehingga mampu mengendalikan nafsu duniawi dan dapat menarik karunia Tuhan.

3) Bunga

Sebagai lambang keikhlasan dalam pemujaan, tidak ada keraguan semua didasari dari segala ketulus ikhlasan yang tumbuh dari sanubari paling dalam. Maknanya manusia harus mampu mengikhlaskan diri dari berbagai ikatan duniawi.

4) Jejahitan, Reringgitan dan Tetuasan

Sebagai lambang ketetapan dan kelanggengan pikiran untuk menuju dharma secara terus- menerus dijalankan menuju jalan Tuhan, mengindari diri dari godaan-godaan keduniawian.

5) Urassari

Letaknya di atas plawa, porosan, tebu, pisang, kekiping dan lainnya dialasi dengan ceper, di atasnya dihiasi dengan berbagai bunga. Bentuk urassari adalah lambang segi empat yaitu bentuk sederhana dari swastika sehingga berbentuk cakra setelah dihias. Urassari yang tersusun dengan jejahitan dan tetuasan akan terlihat berbentuk lingkaran "Padma Astadala" yang merupan stana Ida Sang Hyang Widhi Wasa dengan sembilan penjuru mata angin. Sampian urassari adalah lambang "Padma Astadala" mempunyai makna permohonan kepada Tuhan semoga alam ligkungan

d. Bungkak kehidupan berjalan selaras dan seimbang.

Dalam pelaksanaan yadnya bungkak adalah simbol dari Dewa Nawa Sanga yang berhubungan dengan keserasian alam semesta antara buana agung dan buana alit. Berdasarkan mitologi bungkak digunakan dalam pengelukatan Raden Cupak di Brahma Loka pada pancoran lima yaitu pancoran besi, pancoran tembaga, pancoran selaka, pancoran emas dan pancoran sudamala. Bungkak juga menjadi sarana pada saat Dewi Durga melukat Sang Bima saat mencari Tirta Amerta Kamandalu. Dengan demikian bungkak merupakan salah satu sarana penting dalam pelaksanaan yadnya terutama dalam pembuatan Banten Prayascita, pedudusan agung dan pedudusan alit. Bungkak merupakan simbol dari buana agung yang susunannya terdiri dari 14 lapis (Sapta Loka) sedangkan buana alit terdiri dari 7 lapis (Sapta Petala)(Sumarjana, 1989).

Jenis- jenis bungkak yang digunakan dalam upacara agama ditentukan berdasarkan tingkatan upacara yadnya, tingkatan upacara kecil digunakan bungkak kelapa gading, tingkatan upacara sedang digunakan lima jenis bungkak dan tingkatan upacara besar digunakan sembilan jenis bungkak. Sembilan bungkak yang digunakan seperti bungkak kelapa bulan, bungkak kelapa rangda, bungkak kelapa 
udang, bungkak kelapa be julit, bungkak kelapa gading, bungkak kelapa bojog, bungkak kelapa mulung, bungkak kelapa surya dan bungkak kelapa sudamala.

Hakikat penggunaan bungkak dalam upacara yadnya adalah simbol bahwa dalam kehidupan manusia dan alam sekitarnya menginginkan keserasian sesuai filsafat Tri Hita Karana, ingin mendapatkan kesucian lahir dan batin terbebas dari perbuatan ternoda. Bungkak menjadi simbol terwujudnya keseimbangan antara buana agung dan buana alit merupakan sarana untuk mencapai tujuan dari ajaran Agama Hindu (Wawancara tanggal 14 April 2006 dengan Ida Pedanda Gede Oka Pinatih).

e. Daun Dapdap

Daun Dapdap mempunyai makna kesejukan, pelindung dan menetralisir perbuatan jahat yang dibuat oleh manusia sehingga sering digunakan untuk sarana pengobatan. Penggunan daun dapdap sebagai sarana upakara sebagai sarana penyucian, pelebur segala kotoran yang mengenai upakara atu sesajen baik yang bersumber dari asal bahannya atau kotoran yang muncul saat proses pembuatannya (Lontar Taru Pramana).

f. Uang Kepeng

Keberadaan uang kepeng sudah sangat sulit didapatkan sehingga dalam beberapa hal seperti sesari/sesantun, penebusan, penghargaan tirta dan lain-lain disesuaikan dengan uang yang memiliki nilai tukar yang sah (Pemerintah Daerah Propinsi Bali, 2000). Uang kepeng berasal dari unsur pancadatu (tembaga,emas, besi, perak, dan timah), bentuknya bulatan lambang dari windu, mulai dari bilangan satuan terkecil sehingga bilangan 1 sampai dengan 9 mengandung arti simbolis sesuai dengan urip pengider-ideran. Uang kepeng digunakan untuk sarana melengkapi upakara Panca Yadnya seperti dalam akah banten, orti, dalam buah lis, kwangen dan dapat juga digunakan sebagai sesari serta berfungsi sebagai lamak tamiang, salang, payung pagut, penyeneng, dan lain-lain.

2. Api, Dipa dan Dupa

Dalam persembahyangan api diwujudkan dengan dupa dan dipa. Dipa adalah jenis harum-haruman yang dibakar sehingga menimbulkan bau harum sedangkan dupa dibakar sehingga apinya menyala sebagai lambang Dewa Agni yang memiliki arti dan makna :

a. Sebagai pendeta pemimpin upacara

Pendeta setelah melalui proses upacara daksita secara simbolis telah mati raga, amati aran, amati wesa dan amati sesana yang artinya telah meninggalkan badan wadagnya, mati namanya semula, mengganti atribut dan terlahir kembali mewakili Tuhan memimpin umat untuk kejalan dharma. Api sebagai lambang penuntun umat ada dalam "Isa Upanisad" Mantra 18 (Wiana, 2000) sebagai berikut :

"agne naya supharteraye asman, Visvani dena vayunani vidvan,Yuyudhy asmaj juhuranam eno, Bhuyistham te nama uktim vidhema 
Artinya: Oh Tuhan kuat laksana api, maha kuasa tuntulah kami semua, semua yang hidup kejalan yang baik, segala tingkah laku menuju kepadaMu yang bijaksana, jauhkan dari jalan yang tercela yang jauh daripada $\mathrm{Mu}$, baik penghormatan maupun kata-kata yang hamba lakukan. Dupa berasal dari alam semesta menyala dan asapnya membumbung tinggi ke angkasa dan fenomena ini perlambang penuntun umat dalam melakukan persembahyangan, menghidupkan api dalam diri serta menggerakkannya menuju Tuhan ibarat asap menuju angkasa. Sedangkan dipa yang hanya boleh dipakai sarana pemujaan oleh Pedanda/ Sulinggih adalah lambang kehadiran Tuhan dalam menuntun umatnya. Karena itulah dupa dan dipa mempertajam serta memantapkan pikiran umat dalam melaksanakan persembahyangan. Dipa dan Dupa mempunyai makna pertemuan antara Tuhan dengan umatnya sedangkan posisi Pendeta menjembatani pertemuan tersebut.

b. Sebagai sarana yang menghubungkan sang pemuja dengan yang dipuja

Bagi mereka yang sudah memiliki tingkat Wijnana dan Jnananya sudah tinggi maka mereka sudah mampu menghidupkan api dalam dirinya misalnya dengan cara yoga. Sedangkan bagi mereka yang belum mencapai tingkatan tersebut dan masih awam untuk dapat melakukan pendekatan dengan Tuhan masih memerlukan sarana dari alam sebagai ciptaan Tuhan.

c. Sebagai pebasmi segala kotoran dan pengusir roh jahat Sebelum melakukan persembahyangan seharusnya dalam keadaan bersih secara lahir dan batin. Bersih secara lahiriah dengan mandi, keramas belum lah cukup sebaiknya juga pikiran dan perasaan terfokus pada yang dipuja. Sebelum melakukan muspa, dupa yang sudah menyala diangkat setinggi ulu hati serta diucapkan Mantra " Om Ang dhupa dipastraya namah swaha" yang artinya Om sang Hyang Widhi dengan sinar sucimu sucikanlah diri hamba. Demikian juga bunga yang akan digunakan muspa sebelumnya diasapi agar diberkati kebersihan dari kotoran oleh apinya dupa. Keadaan yang suci dan bersih akan membawa kedalam keadaan yang suci dan bersih dengan yang akan dipuja.

d. Sebagai saksi upacara

Dalam persembahyangan bentuk api yang dilambangkan sebagai saksi upacara sama dengan api sebagai pendeta pemimpin upacara. Api dupa lambang api saksi sedangkan asap api dupa yang membungbung tinggi adalah gerakan rohani menuju angkasa tempat berstananya Ida Sang Hyang Widhi Wasa beserta dewa-dewi sebagai manifestasinya. Api dengan sinarnya adalah penerangan alam ini, berarti Hyang Maha Agni melihat atau saksi segala perbuatan mahkluk di alam semesta.

2. Air

Ada dua jenis air yaitu air bersih yang digunakan untuk mencuci tangan dan mulut sebelum sembahyang dan air suci yang disebut tirtha. Jenis tirtha ada dua macam yaitu tirtha yang dimohon kepada Tuhan dan Bhetara-Bhetari serta tirtha yang dibuat pendeta dengan puja. Tirtha berfungsi untuk 
membersihkan diri dari kotoran maupun kecemasan pikiran. Tirtha digunakan dengan cara dipercikkan di kepala, diminum dan diusapkan di muka sebagai simbolis pembersihan bayu, sabda dan idep. Tirtha bukanlah air biasa tetapi merupakan benda materi yang sakral dapat menumbuhkan perasaan dan pikiran yang suci. Pembuktian manfaat tirtha didasari atas kepercayaan dan keyakinan. Seluruh umat Hindu harus yakin bahwa tirtha sebagai wujud nyata dari karunia Tuhan untuk memberikan wujud kesucian dalam kehidupan. Konsep berpikirnya dalam pembuatan tirtha " sekala niskala" menggunakan sumber air bersih yang telah terbebas dari kuman penyakit, peralatan yang bersih baik tempat pembuatannya maupun tempat penyimpanannya. Berdasarkan fungsinya tirtha dalam upacara yadnya dibedakan : tirtha pembersihan, tirtha pengelukatan, tirtha wangsupada/banyun cokor/pekuluh, tirtha pemanah, tirtha penembak dan tirtha pengentas.

Makna banten berdasarkan bentuk jejahitan yang biasa dibuat mempunyai makna (Arwati, 1993), seperti:

1. Bentuk Segi Tiga

Bentuk segi tiga dapat dilihat pada jejahitan tangkih, celemik, ituk-ituk dan celekontong. Bentuk- bentuk seperti ini memiliki makna :

a. Tri Premana : Sabda, Bayu dan Idep

b. Tri Guna: Satwam, Rajas dan Tamas

c. Tri Kaya Parisudha : Manacika, Kayika dan Wacika

d. Tri Kona: Utpeti, Sthiti dan Pralina

Kesemua ini terdiri dari tiga unsur yang merupakan satu kesatuan yang utuh dan selalu ada dalam pembentukannya.

2. Bentuk Segi Empat

Bentuk segi empat dapat dilihat dalam taledan dan ceper, memiliki makna :

a. Catur Purusa Artha : Dharma, Artha, Kama dan Moksha

Merupakan empat tujuan yang patut dilakukan dan selalu dicari dalam kehidupan baik lahir maupun batin.

b. Catur Marga : Bhakti Marga, Karma Marga, Jnana Marga dan Raja Yoga Marga

Merupakan empat jalan untuk mencapai kesempurnaan hidup dalam mendekatkan diri Ida Hyang Widhi Wasa yang menjadi tujuan hidup.

3. Bentuk Bulat atau Bundar

Bentuk Bulat atau Bundar dapat dilihat pada Tamas, Kulit Sesayut, Kulit Tebasan, Sampyan Nagasari, Kembang dan Urassari. Bentuk ini memiliki makna :

a. Nemu Gelang kebulatan yaitu Panca Dewata, Asta Iswara dan Dewata Nawa Sanga

b. Windu atau Kosmos atau Alam Semesta

Dalam tatwa Agama Hindu disebut Brahmanda yang artinya keluar dari Brahma (Sudarsana dalam kursus membuat banten Piodalan Alit dan Otonan tanggal 31 Juli 2006, di UNHI Denpasar).

Banten Prayascita terdiri dari beberapa komponen didalamnya, disusun sesuai kaidahnya. Dalam setiap komponen Banten Prayascita memiliki makna berdasarkan bentuk reringgitannya, seperti berikut: 
1. Kulit Sesayut/ Tebasan

Mempunyai makna pembebasan, perlindungan atau penebusan, umpamanya dari kotor, ternoda, terbelenggu atau tertekan menjadi suci, tenang dan tenteram dalam hal yang bersifat spritual (Mas Putra, 2001: 73-74).

2. Kulit Peras

Melambangkan Panca Maha Butha, apabila tidak digunakan walaupun isinya tetap sama maka tidak akan disebut "peras", namanya berbeda, umpama pengiring dan lain-lain (Mas, 2000: 105).

3. Tipat Kukur

Mempunyai makna sebagai kekuatan angin sebagai pembersih segala kotoran

4. Tulung

Artinya tolong sebagai lambang saling tolong menolong, welas asih yang merupakan salah satu sifat Tuhan untuk semua mahkluk yang ada di alam semesta. Jumlahnya ada 5 buah bermakna Panca Indera maksudnya memohon kepada Ida Hyang Widhi Wasa agar kita dapat mengendalikan panca Indera (Sudarsana I B Putu, 2002).

5. Kojong Rangkap

Merupakan simbol Utpeti, Sthiti dan Pralina

6. Sampyan Nagasari

Mempunyai makna untuk memohon sarining merta

7. Sampyan peras

Merupakan simbol alam fana dan alam baka adalah tunggal. Bentuknya yang bundar dan penampangnya sama (Aiswarya sekala niskala). Sampyan ini juga merupakan simbol cara berhubungan dengan dunia sesuai ajaran "catur yoga", secara simbolis terdapat lidi sebanyak empat katih menghubungkan dasar dengan ujung sampyan.

8. Banten Pabersihan

Tepung tawar sebagai kekuatan Sang Hyang Iswara untuk memohon penyucian mengenai sebel handel, letehin jagat dan sarira.

Daun dapdap yang digilas dan dicampur minyak wangi sebagai simbol kekuatan Sang Hyang Brahma untuk memohon penyucian kehadapan beliau mengenai berbagai macam bentuk yang bersifat wiguna.

Lenge wangi sebagai simbol kekuatan Sang Hyang Maha Dewa untuk memohon penyucian kehadapan beliau akibat perbuatan satru/ kejahatan.

Sigsig sebagai simbol kekuatan Sang Hyang Wisnu untuk memohon penyucian mengenai gering sabsab merana.

Burat wangi sebagai simbol kekuatan Sang Hyang Siwa untuk memohon penyucian kehadapan beliau dari segala kotoran.

9. Penyeneng

Penyeneng adalah simbol Dewa yang memberi kehidupan, berasal dari kata nyeneng yang artinya hidup, penyeneng artinya penghidup atau pemberi hidup.

10. Babuu

Berupa lilit linting yang maknanya adalah mencapai kesucian bersatu dengan Tuhan dalam ketenangan, menyadarkan diri, menjalankan api suci dan kebenaran dalam diri. Lawat buah sebagai simbol dari kelurusan hati dan kejujuran jika ingin mencapai kesucian. Lawat nyuh adalah simbol keselamatan manusia pada saat pertama diciptakan Sang Hyang Widhi Wasa. Canggah menek canggah tuwun adalah simbol dari Brahma dan wisnu 
sebagai pencipta dan pemelihara.

11. Lis

Bentuk jejahitan dari lis dalam Banten Prayascita biasanya menggunakan senjata Tri Murti dalam upakara tingkatan kecil atau madya sedangkan untuk upakara yang besar digunakan senjata PancaDewata Nawa Sanga. Senjata Tri Murti terdiri dari Gada, Cakra dan Padma, sedangkan senjata Panca Dewata Nawa Sanga Bajra,Gada, Nagapaksa, Cakra dan Padma. Penyusunannya paling bawa gada, tengah padma dan paling atas cakra. Penyusunan senjata Panca Dewata Nawa: paling bawah Nagapaksa kemudian Gada, ditengah Padma, Cakra dan paling atas Bajra (wawancara dengan ibu Wendri tanggal 24 Mei 2006). Makna dari lis merupakan inti dari permohonan adalah kesucian (Sudarsana I B Putu, 2002) sedangkan menurut Wendri dari hasil wawancara memiliki makna kekuatan magis dan religius melebur semua mala dari yang kotor menjadi bersih dan suci.

12. Padma

Reringgitan dibuat dari janur kelapa gading berbentuk seperti kembang padma. Lis padma merupakan senjata Sang Hyang Siwa yang memiliki makna kekuatan penyucian.

Selain jejahitan di atas beberapa komponen lain dalam Banten Prayascita memiliki makna sebagai berikut :

a. Nasi Soda

Simbol pradana tatwa yang mengandung makna Sang Hyang Ayu, memohon kerahayuan kehadapan Sang Hyang Siwa.

b. Tumpeng

Lima buah tumpeng simbol manca giri dan mempunyai makna kekuatan Sang Hyang Panca Dewata.

c. Jajan, tebu dan pisang

Jajan begina merah dan putih memiliki simbol permohonan kehadapan Ida Hyang Widhi Wasa baik bersifat purusa maupun prakerti. Jajan uli merah putih simbol permohonan kedamaian kehadapan Ida Hyang Widhi Wasa sekala niskala.

d. Tebu

Simbolpermohonan amertha Ida Hyang Widhi Wasa

e. Pisang

Bagian dari buah-buahan simbol amerta sanjiwangi agar umat memilki sifat bijaksana, agar dapat dianugrahi sesuai dengan buah karma pahalanya.

f. Salak

Simbol amerta kamandalu agar selalu dianugrahi kesehatan fisik, mental, akal dan budi

g. Mangga (sejenisnya buah berwarna kuning)

Simbol amerta kundalini, dianugrahi kemakmuran dan kesejahteraan.

h. Manggis

Simbol amerta pawitra agar senantiasa memiliki hati yang ikhlas dan jujur untuk menuju tingkat kesucian.

i. Kacang Saur, Sambal dan Garam

Mempunyai makna permohonan kehadapan Ida Hyang Widhi Wasa agar dikaruniai kekuatan, keteguhan iman (kacang), kedamaian (saur), kesidian (sambal), dan garam (peleburan). 


\section{SIMPULAN}

Banten Prayascita merupakan salah satu banten penting, hampir selalu digunakan dalam pelaksanaan yadnya dan tersusun dari beberapa komponen membentuk satu kesatuan untuk mengwujudkan fungsi utamanya sebagai penyucian. Selain mempunyai fungsi utama penyucian, Banten Prayascita memiliki fungsi lainnya sebagai alat konsentrasi, korban suci dan sarana pendidikan. Dalam pembuatan Banten Prayascita ditemukan pendidikan seni dan budaya dengan menciptakan jejahitan dengan reringgitanyang indah, melukiskan simbol-simbol dewa yang mencermikan nilai keindahan yang sangat tinggi.Mulai dari proses pembuatannya harus didasari atas ketulus ikhlasan umat dan kesucian pikiran, keheningan perasaan dalam menwujudkan bakti kehadapan Ida Hyang Widhi Wasa. Setiap komponen yang ada didalamnya memiliki fungsi dan makna secara nilai filosofi dengan harapan mampu menjaga keseimbangan, keharmonisan antara manusia dengan Ida Hyang Widhi Wasa beserta manifestasinya.

\section{DAFTAR PUSTAKA}

Arwati, N. M. S. (1993). Jenis Jenis Banten Sesayut. Denpasar: Upada Sastra.

Mas, P. I. G. A. (2000). Upacara Dewa Yadnya. Denpasar.

Pemerintah Daerah Propinsi Bali. (2000). Arti dan fungsi sarana upakara. Denpasar: Pemerintah Daerah Propinsi Bali.

Rana, T. M. (1972). Tjara Membuat Lis di Pajangan (Gianjar). Denpasar: Universitas Udayana.

Rana Tjokorde Made. (1972). Tjara membuat lis di Pajangan (Gianjar). Denpasar: Universitas Udayana.

Rasni, N. W. (1983). Fungsi Upacara Sesayut Prayascita Gumi dalam Upacara Butha Yadnya di Kabupaten Badung. Denpasar: Universitas Hindu Indonesia.

Rianingsih Putu. (2004). Faktor-faktor yang berpengaruh terhadap pengembangan usaha Canang Sari di Kabupaten Badung. Denpasar: Universitas Hindu Indonesia.

Sudarsana I B Putu. (2002). Ajaran agama Hindu (filsafat yadnya). Denpasar: Mandara Sastra.

Sudarsana I B Putu dkk. (n.d.). Himpunan tetandingan upakara yadnya. Denpasar: Yayasan Dharmaacarya.

Suika I Wayan. (1981). Arti dan fungsi lis dalam upacara piodalan di Pura Jaganatha. Denpasar: Universitas Hindu Indonesia.

Sumarjana, I. W. (1989). Peranan Bungkak dalam Upacara Yadnya Ditinjau dari Segi Pendidikan. Denpasar: Universitas Hindu Indonesia.

Titib I Made. (2003). Teologi simbol - simbol dalam agama Hindu. Surabaya: Paramitha.

Wiana, I. K. (2000). Arti dan Fungsi Sarana Persembahyangan. Surabaya: Paramita. 